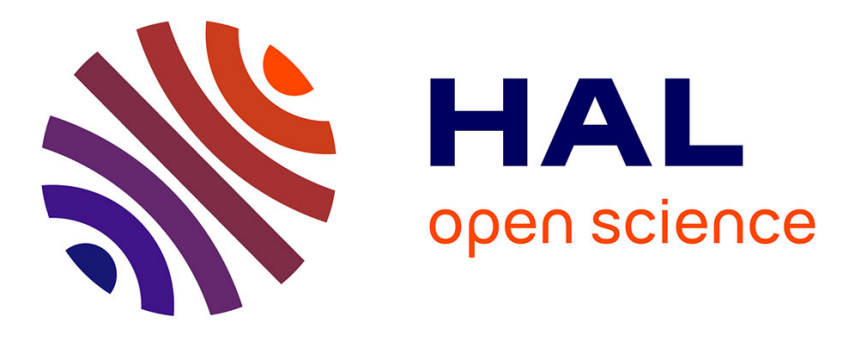

\title{
Disassortative Sexual Mixing among Migrant Populations in the Netherlands: a Potential for HIV/STI Transmission?
}

Maaike van Veen, Merlijn Kramer, Eline Op de Coul, Petra van Leeuwen, Onno de Zwart, Marita van de Laar, Roel Coutinho, Maria Prins

\section{To cite this version:}

Maaike van Veen, Merlijn Kramer, Eline Op de Coul, Petra van Leeuwen, Onno de Zwart, et al.. Disassortative Sexual Mixing among Migrant Populations in the Netherlands: a Potential for HIV/STI Transmission?. AIDS Care, 2009, 21 (06), pp.683-691. 10.1080/09540120802511984 . hal-00513477

\section{HAL Id: hal-00513477 https://hal.science/hal-00513477}

Submitted on 1 Sep 2010

HAL is a multi-disciplinary open access archive for the deposit and dissemination of scientific research documents, whether they are published or not. The documents may come from teaching and research institutions in France or abroad, or from public or private research centers.
L'archive ouverte pluridisciplinaire HAL, est destinée au dépôt et à la diffusion de documents scientifiques de niveau recherche, publiés ou non, émanant des établissements d'enseignement et de recherche français ou étrangers, des laboratoires publics ou privés. 

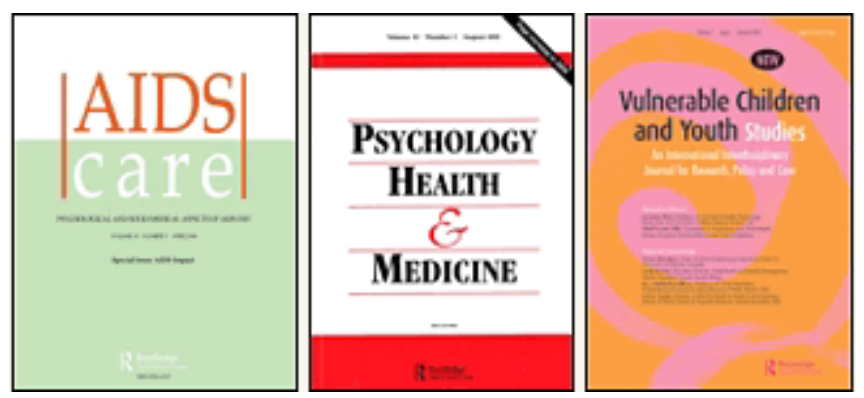

\section{Disassortative Sexual Mixing among Migrant Populations in the Netherlands: a Potential for HIV/STI Transmission?}

\begin{tabular}{|r|l|}
\hline Journal: & $\begin{array}{l}\text { AIDS Care - Psychology, Health \& Medicine - Vulnerable Children } \\
\text { and Youth Studies }\end{array}$ \\
\hline Manuscript ID: & AC-2008-05-0192.R1 \\
\hline Journal Selection: & AIDS Care \\
\hline Keywords: & HIV, sexual mixing, migrants, Netherlands, transmission \\
\hline
\end{tabular}

\section{今 scholarONE" \\ Manuscript Central}


Disassortative Sexual Mixing among Migrant Populations in the Netherlands: a Potential for HIV/STI Transmission?

Word count (including abstract): 3241 


\section{Abstract}

To gain insight into the transmission of HIV and STI among large migrant groups in the Netherlands, we studied the associations between their demographic and sexual characteristics, in particular condom use, and their sexual mixing patterns with other ethnic groups. In 20022005, cross-sectional surveys were conducted among migrants from Surinam (Afro- and Hindo-), the Netherlands Antilles, Cape Verde, and Ghana at social venues in three large cities. A questionnaire was administrated and a saliva sample was collected for HIV antibody testing. Of 2105 migrants recruited, 1680 reported sexual contacts, of whom $41 \%$ mixed sexually with other ethnicities, including the indigenous Dutch population. Such disassortative mixing was associated with being second generation migrants, having several sexual partners, and having a steady and concurrent casual partner. Less disassortative mixing occurred in participants reporting visiting the country of origin. The association between condom use and sexual mixing differed by gender, with men using condoms inconsistently being most likely to be mixing with the Dutch indigenous population. HIV infection and recent STI treatment were not associated with disassortative mixing. This study shows substantial sexual mixing among migrant groups. Since disassortative mixing is more prevalent in second generation migrants, it might increase in the upcoming years. The mixing patterns in relation to concurrency and the reported condom use in this study suggest a possibly increased level of HIV/STI transmission not only within migrant groups but also between migrant groups, especially via men who mix with the indigenous population and via migrant women who mix with non-Dutch casual partners. Although the observed HIV prevalence in migrants $(0.6 \%)$ is probably too low to lead 
to much HIV transmission between ethnicity groups, targeted prevention measures are needed to prevent transmission of other STI.

Keywords: migrants; Netherlands; sexual mixing; concurrency 


\section{Introduction}

Over the years, the number of HIV diagnoses in Europe has increased among persons infected through heterosexual contact, mainly because diagnoses have increased among persons originating from countries with generalized HIV epidemics (EuroHIV, 2006). This rise has also been observed in the Netherlands (Op de Coul, Fennema J.S., \& Hoek J. van de, 2003), but has recently leveled off, possibly because of more restrictive asylum policies (Veen MG van et al., 2007).

In the Netherlands, migrants originating from Surinam and the Antilles (two former Dutch colonies) form one of the largest migrant groups (CBS). In addition, we have a large community of sub-Saharan Africans (CBS). In 1997, HIV prevalence was $0.8 \%$ among migrants from the Netherlands Antilles, $0.3 \%$ among Afro-Surinamese and $1.8 \%$ among Ghanaian migrants living in Amsterdam (Gras, Weide, Langendam, Coutinho, \& van den Hoek, 1999). These prevalences are higher than the estimated prevalence of $0.2 \%$ for the general population in the Netherlands in 2005 (Op de Coul, Sighem, \& Laar, 2006).

The importance of migration in the spread of HIV/STI has been discussed widely (Quinn, 1994) and it is considered as one of many social factors that have contributed to the AIDS epidemic (Decosas \& Adrien, 1997). Mobile populations or people who have recently changed residence are likely to be at higher risk for HIV, in particular migrant men (Lurie et al., 2003). Social networks may power the spread of HIV (Morris, 1997; Rothenberg et al., 1998) and mixing patterns influence the risk of specific infections (Aral et al., 1999). Hertog described that disassortative sexual mixing in combination with high rates of partner change tend to increase the overall size of the HIV epidemic (Hertog, 2007). Studies of socio-cognitive 
determinants of protective behavior among migrants from HIV endemic areas are limited. Wiggers et al. showed that next to social cognitive factors specified by the theory of planned behaviour, the effect of ethnicity of the partner, also was a significant determinant of condom use in ethnic minorities (Wiggers, de Wit, Gras, Coutinho, \& van den Hoek, 2003).

In a previous study among migrants in the Netherlands, sexual contacts in the country of origin were frequently reported, as were sexual contacts between ethnicity groups in the Netherlands (Gras, Weide, Langendam, Coutinho, \& van den Hoek, 1999). In 2005, another study showed that older male travelers of Surinamese and Antillean origin are at risk for crossborder heterosexual transmission of HIV and sexually transmitted infections (STI) because of their frequent travel to the home country and their unprotected sexual contacts in both countries (Kramer MA et al., 2008). However, little is known about the potential for HIV/STI transmission within and among migrant groups. To gain insight into these dynamics, we studied how condom use and other risk-related characteristics of Surinamese, Antillean, and sub-Saharan African migrants living in the Netherlands, might be associated with their sexual mixing patterns with other ethnic groups, including the indigenous Dutch population. 


\section{Methods}

\section{Study population and methods}

From 2002 to 2005, cross-sectional community-based HIV surveys were carried out in three large urban areas (Rotterdam, Amsterdam, and The Hague) in the Netherlands among migrants from HIV-endemic countries i.e. countries with an estimated adult HIV prevalence over $1 \%$.

Participants were included in the study if they or one of their parents were born in Surinam, the Netherlands Antilles, Aruba, Ghana, or Cape Verde; if they were aged between 18 and 55 years, and currently lived in the Netherlands. Professionally instructed interviewers approached potential participants at cultural meeting places, such as community centers, festivals, and churches. Based on notes of the recruitment team, the participation among migrants approached was about $60 \%$. Those who declined, stated that they did not have time, did not want to talk about their sexual behavior, or that they might participate at another time. No demographic differences between responders and non-responders were observed.

Interviewers indicated that migrant-mothers accompanied by their children were more reluctant to participate as were men in the companionship of their wife.

Participants were interviewed face-to-face, using a structured questionnaire covering demographic characteristics, sexual behavior, ethnicity of sexual partners, visits to the country of origin, and HIV/STI testing. Subsequently, a saliva sample was collected for HIV antibody testing by enzyme linked immuno-assay (ELISA), Wellcozym GACELISA (Murex Diagnostics, Abbott Park, USA) was used in 2002, and Vironostika (BioMerieux, France) in 2003-2005, as GACELISA was no longer available. Reactive samples were retested with the 
VIDAS HIV duo (BioMerieux, France). Those reactive on the second ELISA were classified as HIV-positive. Non-reactive samples on the second ELISA were subjected to a Western Immunoblot (InnoLia, Innogenetics, Belgium), to achieve the decisive test result. All respondents received 10 euros to cover any expenses for participation. The ethical committees of TNO Research and the Academic hospital in Utrecht, which are acknowledged by the national body involving research on human subjects, approved the study. Verbal informed consent was obtained of all participants.

\section{Statistical analysis}

Multinomial regression analyses were used to study the association between condom use and other characteristics with sexual mixing. For the analyses, participants were categorized into four mixing groups for potentially intercultural transmission of STI/HIV, based on the ethnicity of their most recent one to four sexual partner(s) in the six months preceding the study: (1) assortative mixing only (reference group), (2) disassortative mixing with indigenous Dutch, (3) disassortative mixing with non-Dutch, (4) disassortative mixing with both indigenous Dutch and non-Dutch partners. If a participant had more than 4 partners in the past 6 months, information was obtained on the 4 most recent partners to limit recall bias and because of the maximum length of the interview. Only participants with at least one heterosexual (non-commercial) partners were included $(n=1680 / 2105)$. Disassortative sexual mixing was defined as a sexual partnership in which the ethnicity differed. Ethnicity of the participant was defined by country of birth. If the participant was born in the Netherlands, the parents' country of birth determined ethnicity, with the mother's being decisive. Ethnicity of the partner(s) was defined by the participant. 
For the analyses, all variables that were significantly associated with the outcome variable $(\mathrm{p}<0.10)$ in the univariate analysis were considered for entry in the multivariate model (backwards selection). Condom use was included in all models since this was our main variable of interest. It was divided into three categories: (1) consistent condom use with all partner(s) (either steady and/or casual), (2) inconsistent condom use with steady partner but, if having casual partners, consistent condom use with them and (3) inconsistent condom use with casual partner(s), regardless of consistent or inconsistent condom use with steady partners. Potential other determinants evaluated were demographic factors, sexual behavior other than condom use, visits in country of origin, and HIV/STI testing behavior. Demographic factors included the sex and ethnicity of the participant; age, country of birth, and years of residence in the Netherlands; educational level, marital status, and generation (defined by country of birth of the participant). Sexual determinants included total number of reported partners in the past 5 years; having only a steady partner; having only casual partners (with detailed information on the 4 most recent partners in the six months preceding the study); having a concurrent casual partner while having a steady partner (i.e., for at least 6 months); having commercial sex contacts, and having anal sex contacts. Travel behavior was defined by one or more visit to the country of origin in the 5 years preceding the study. HIV/STI testing behavior included STI treatment, HIV testing history, and results of prior HIV testing. We checked for interactions with gender in the final model. Finally, we repeated our analyses on sexual mixing, focusing only on participants reporting two or more partners $(n=557 / 1680)$. Analyses were carried out using the SAS software 9.1.3 (SAS Institute, Inc., Cary, North Carolina). 


\section{Results}

\section{Characteristics of the study population}

In total, 2105 participants were enrolled in the study between 2002 and 2005, of whom 1193 were men $(57 \%)$. Of the total, $328(16 \%)$ were Hindo-Surinamese migrants, $449(21 \%)$ Afro-Surinamese, 710 (34\%) Antilleans, 425 (20\%) Ghanaian, and 193 (9\%) Cape Verdeans. Of all participants, $77 \%$ were born in the country of origin (first-generation migrants) with a median age at migration of 20 years. Antillean and Ghanaian migrants were more often firstgeneration migrants than were Hindo-, Afro-Surinamese, or Cape Verdean migrants (90\%, $86 \%$ versus $63 \%, 65 \%, 57 \%$, respectively). Eleven saliva samples tested positive for HIV antibodies (0.6\% [95\% CI 0.3-1.0\%]). Of all migrants, 340 (16\%) reported an STI check up in the previous year. Of those tested, $22 \%$ had been treated for an STI.

(Table 1)

\section{Associations with disassortative sexual mixing}

Of the 2105 participants, $1680(80 \%)$ reported sexual contacts with at least one noncommercial steady and/or casual partner, with known ethnicity. As shown in Table 1, 986 (59\%) reported partners of the same ethnicity or assortative mixing (group 1, reference group); $244(15 \%)$ reported only indigenous Dutch partners (group 2); 361 (21\%) reported non-Dutch disassortative mixing (group 3), and 89 (5\%) reported disassortative mixing with both indigenous Dutch and non-Dutch partners (group 4).

The multivariate multinomial regression analyses found significant associations between the three disassortative mixing groups and gender, condom use, concurrent casual 
partner, ethnicity, second-generation migrants, educational level, number of partners in the previous 5 years, and visits to home country (Table 2). Condom use and gender were combined in the multivariate analyses, since we found a significant interaction between these variables.

Compared to women who use condoms consistently, men who inconsistently used condoms with steady partners or with casual partners were more likely to mix with only indigenous Dutch (group 2). Also, men who inconsistently used condoms with casual partners were more likely to be in the $4^{\text {th }}$ group, mixing with both indigenous Dutch and non-Dutch. Women who inconsistently used condoms with steady partners were less likely to mix with Dutch persons only or with both Dutch and non-Dutch than were women who used condoms consistently. In contrast, women reporting inconsistent condom use with casual partners were more likely to mix only with partners of non-Dutch ethnic origin than were women who used condoms consistently. Participants with a concurrent casual partner were more likely to mix disassortatively, whereas participants who visited the home country were less likely to mix disassortatively, regardless of the ethnicity of the disassortative partners. Afro-Surinamese migrants were more likely to mix with Dutch partners and also with partners of different nonDutch ethnic background. In contrast, Hindo-Surinamese were less likely to mix with nonDutch partners. Second-generation migrants were more likely to mix with Dutch only and also with non-Dutch. Participants with 4 or more reported sexual partners were more likely to mix with both Dutch and non-Dutch. In addition, participants reporting 7 partners or more were more likely to mix with non-Dutch. Those with middle educational level were less likely to have Dutch partners, whereas those with a high educational level were more likely to have non-Dutch partners.

(Table 2) 
Associations with disassortative sexual mixing in participants with two or more partners

Of all participants, 557 (26\%) reported two or more partners with known ethnicity (Table 3). Compared to women with two or more partners who consistently used condoms, men in all three groups of condom use were more likely to mix with indigenous Dutch. In addition, men who consistently used condoms with all partners or men who inconsistently used condoms with steady partners only were more likely to mix with both Dutch and non-Dutch partners. Participants who traveled to their home country were less likely to mix with both Dutch and non-Dutch partners. The analysis of the total group $(n=1680)$, the same was true for mixing with Dutch only and mixing with non-Dutch only. However, the number of participants included in the analysis was smaller $(\mathrm{n}=557)$.

(Table 3) 


\section{Discussion}

Our main finding is that a substantial proportion of migrants mixed sexually with persons of other ethnicities, including the indigenous Dutch population. Since disassortative mixing increases from first- to second-generation migrants, it is likely to increase further in the coming years. We were especially interested in the association between condom use and sexual mixing. This effect differed by gender, with men in general being more likely to mix disassortatively than women, and men who inconsistently used condoms with casual partners being more likely to mix with both indigenous Dutch and non-Dutch. These findings indicate that especially men using condoms inconsistently are the bridge for HIV/STI transmission between different population groups.

Because cultural values are shared within ethnic groups, individuals are more likely to have relationships with members of their own groups than with others. Of our subjects, $59 \%$ reported assortative mixing patterns, which is lower than in a study among American adolescents reporting $78 \%$ assortative ethnic mixing (Ford, Sohn, \& Lepkowski, 2002). Some studies support the view that assortative mixing fuels the spread of STI within subpopulations (Aral, 2000; Laumann \& Youm, 1999). This suggests that assortative mixing may actually reduce the transmission of STI between subpopulations. Of migrants who reported STI testing in our study, 22\% had an STI diagnosed, which is comparable with $21 \%$ positive STI diagnoses among Surinamese and Antillean who visit STI clinics (Veen MG van et al., 2007). A survey among black Africans in England found that $22 \%$ of respondents had previously had an STI diagnosis (Sadler et al., 2007). These findings support the suggestion that within 
migrant groups, in which inconsistent condom use is high in steady partnerships, assortative mixing contributes to the transmission of STI within the subpopulation.

We found that second generation migrants were more likely to mix disassortive than first generation migrants. Second generation migrants are likely to assimilate better to the culture of the country of residence than first generation migrants and are therefore more likely to choose sexual partners of the indigenous population in the country of residence. The tendency of conforming behaviour is subscribed by a study by Hosper et al. (2007) in which they showed that behavioural risk factors (e.g. smoking, physical inactivity) in two generations of non-Western migrants seem to converge towards the prevalence rates in the Dutch population (Hosper, Nierkens, Nicolaou, \& Stronks, 2007). First generation migrants might hold on to their own culture, as they were not born in the country of residence. The proportion migrants who have a partner of another ethnic group will likely increase the coming years, since more second generation migrants' turn into adults and first generation migrants giving birth to the next generation.

We found that having a concurrent casual partner was reported by almost one in four migrants and that concurrency is associated with disassortative mixing. Its prevalence in our study is high when compared to American studies that, for example, found $12 \%$ concurrent sexual partnerships among American women and 11\% among American men (Adimora et al., 2002; Adimora, Schoenbach, \& Doherty, 2007). Concurrency is an important factor in the spread of HIV/STI (Morris \& Kretzschmar, 1997) and has been cited to help explain Africa's high HIV prevalence (Halperin \& Epstein, 2004). Concurrent partnerships may involve in either assortative or disassortative mixing. Partnerships that involve the latter, as concurrent partners, can rapidly accelerate the spread of STI/HIV in a population (Koumans et al., 2001; 
Doherty, Shiboski, Ellen, Adimora, \& Padian, 2006; Gorbach, Drumright, \& Holmes, 2005). In our study, concurrency was independently associated with disassortative mixing with Dutch and/or non-Dutch in multivariate analyses. In some groups, having concurrent sexual partners is culturally accepted. Although this could affect the transmission of HIV, rates of HIVinfection remain relatively low in these migrant groups. The low prevalence was not associated with disassortative mixing, nor was self-reported STI. Further research into concurrency is needed to fully understand the impact and implication of concurrent partnerships on the spread of STI.

The findings of our study are subject to some limitations. First of all, interview studies have the limitation that interviewers might select favorable answers, possibly resulting in interview bias. We tried to minimize this bias by training the interviewers thoroughly preceding fieldwork (UNAIDS/WHO, 2000). Another potential weakness of this method is that it reaches only the most actively socializing subset of the group of migrants, who may be atypical in their sexual behavior with respect to the group as a whole. In addition, participants in surveys into sexual behavior are generally atypical in being more sexually experienced and less likely to perceive taboos on discussing sex (Dunne et al., 1997). Finally, the recruitment was conducted through convenience sampling in hard-to-reach minority communities, since a random sample was precluded by the anonymous nature of our questionnaire. Such recruitment could have biased the results of our study, although we tried to contact as many community group members as possible, by approaching migrants at different social venues at different times (Ostrow DG \& Kessler RC; UNAIDS/WHO). Moreover, we used information of key figures of each migrant community in mapping all possible social venues preceding the actual field work. Despite such limitations, we feel our study gives insight into the associations 
between (sexual) characteristics of a community sample of migrant groups and their sexual mixing patterns with indigenous Dutch and non-Dutch.

In conclusion, this study shows substantial disassortative sexual risk behavior among migrant groups in the Netherlands. Since disassortative mixing is more prevalent in secondgeneration migrants compared to first-generation, it might increase further in the upcoming years. The mixing patterns, the concurrency and the inconsistent condom use found in this study suggest further possible HIV/STI transmission within migrant groups but also between migrant groups. Transmission of HIV between ethnicity groups will probably be minimized by its low prevalence in these groups, but targeted prevention measures are recommended to prevent transmission of other STI. Further mathematical modeling studies are needed to investigate which factors (e.g. sexual risk behavior, HIV prevalence) determine HIV transmission from migrants to the indigenous population in the country they share. 


\section{Acknowledgements}

The authors acknowledge all participants in this study for their willingness to cooperate. We thank the interviewers and Michel Wagemans for their contributions to the fieldwork of the survey. Ronald Geskus is acknowledged for his contribution to the statistical analyses and Lucy Philips for editing the final manuscript. The study was partly supported by a grant of the AIDS Foundation, the Netherlands (grant no 7015). 


\section{REFERENCES}

Adimora, A. A., Schoenbach, V. J., Bonas, D. M., Martinson, F. E., Donaldson, K. H., \& Stancil, T. R. (2002). Concurrent sexual partnerships among women in the United States. Epidemiology, 13(3), 320-327.

Adimora, A. A., Schoenbach, V. J., \& Doherty, I. A. (2007). Concurrent sexual partnerships among men in the United States. Am J Public Health, 97(12), 2230-2237.

Aral, S. O. (2000). Patterns of sexual mixing: mechanisms for or limits to the spread of STIs? Sex Transm Infect, 76(6), 415-416.

Aral, S. O., Hughes, J. P., Stoner, B., Whittington, W., Handsfield, H. H., Anderson, R. M., et al. (1999). Sexual mixing patterns in the spread of gonococcal and chlamydial infections. Am J Public Health, 89(6), 825-833.

CBS. (2007). Population statistics; Statline databank: http://statline.cbs.nl [Electronic Version]. Statistics Netherlands. Retrieved 17-08-2007 from http:statline.cbs.nl.

Decosas, J., \& Adrien, A. (1997). Migration and HIV. Aids, 11 Suppl A, S77-84.

Doherty, I. A., Shiboski, S., Ellen, J. M., Adimora, A. A., \& Padian, N. S. (2006). Sexual bridging socially and over time: a simulation model exploring the relative effects of mixing and concurrency on viral sexually transmitted infection transmission. Sex Transm Dis, 33(6), 368373.

Dunne, M. P., Martin, N. G., Bailey, J. M., Heath, A. C., Bucholz, K. K., Madden, P. A., et al. (1997). Participation bias in a sexuality survey: psychological and behavioural characteristics of responders and non-responders. Int J Epidemiol, 26(4), 844-854.

EuroHIV. (2006). HIV/AIDS Surveillance in Europe. End-year report 2005. (No. No. 73). SaintMaurice: Institut de veille sanitaire.

Ford, K., Sohn, W., \& Lepkowski, J. (2002). American adolescents: sexual mixing patterns, bridge partners, and concurrency. Sex Transm Dis, 29(1), 13-19.

Gorbach, P. M., Drumright, L. N., \& Holmes, K. K. (2005). Discord, discordance, and concurrency: comparing individual and partnership-level analyses of new partnerships of young adults at risk of sexually transmitted infections. Sex Transm Dis, 32(1), 7-12.

Gras, M. J., Weide, J. F., Langendam, M. W., Coutinho, R. A., \& van den Hoek, A. (1999). HIV prevalence, sexual risk behaviour and sexual mixing patterns among migrants in Amsterdam, The Netherlands. Aids, 13(14), 1953-1962.

Halperin, D. T., \& Epstein, H. (2004). Concurrent sexual partnerships help to explain Africa's high HIV prevalence: implications for prevention. Lancet, 364(9428), 4-6.

Hertog, S. (2007). Heterosexual behavior patterns and the spread of HIV/AIDS: the interacting effects of rate of partner change and sexual mixing. Sex Transm Dis, 34(10), 820-828.

Hosper, K., Nierkens, V., Nicolaou, M., \& Stronks, K. (2007). Behavioural risk factors in two generations of non-Western migrants: do trends converge towards the host population? Eur $J$ Epidemiol, 22(3), 163-172.

Koumans, E. H., Farley, T. A., Gibson, J. J., Langley, C., Ross, M. W., McFarlane, M., et al. (2001). Characteristics of persons with syphilis in areas of persisting syphilis in the United States: sustained transmission associated with concurrent partnerships. Sex Transm Dis, 28(9), 497503.

Kramer MA, Veen MG van, Op de Coul ELM, Geskus R, Coutinho RA, Laar MJW van de, et al. (2008). Migrants travelling to their country of origin: a bridge population for HIV transmission? [submitted]. 
Laumann, E. O., \& Youm, Y. (1999). Racial/ethnic group differences in the prevalence of sexually transmitted diseases in the United States: a network explanation. Sex Transm Dis, 26(5), 250261.

Lurie, M. N., Williams, B. G., Zuma, K., Mkaya-Mwamburi, D., Garnett, G., Sturm, A. W., et al. (2003). The impact of migration on HIV-1 transmission in South Africa: a study of migrant and nonmigrant men and their partners. Sex Transm Dis, 30(2), 149-156.

Morris, M. (1997). Sexual networks and HIV. Aids, 11 Suppl A, S209-216.

Morris, M., \& Kretzschmar, M. (1997). Concurrent partnerships and the spread of HIV. Aids, 11(5), 641-648.

Op de Coul, E. L. M., Fennema J.S., \& Hoek J. van de, e. (2003). HIV-infecties en AIDS in Nederland; prevalentie en incidentie 1987-2002. In (pp. 1-9). Alphen aan de Rijn: Van Zuiden Communications b.v.

Op de Coul, E. L. M., Sighem, A. v., \& Laar, M. J. W. v. d. (2006). Schatting van het aantal volwassenen met hiv/AIDS in Nederland in 2005. Infectieziekten Bulletin, 17(11), 398-403.

Ostrow DG, \& Kessler RC. (1993). Methodological Issues in AIDS behavioral Research.

Quinn, T. C. (1994). Population migration and the spread of types 1 and 2 human immunodeficiency viruses. Proc Natl Acad Sci U S A, 91(7), 2407-2414.

Rothenberg, R. B., Potterat, J. J., Woodhouse, D. E., Muth, S. Q., Darrow, W. W., \& Klovdahl, A. S. (1998). Social network dynamics and HIV transmission. Aids, 12(12), 1529-1536.

Sadler, K. E., McGarrigle, C. A., Elam, G., Ssanyu-Sseruma, W., Davidson, O., Nichols, T., et al. (2007). Sexual behaviour and HIV infection in black-Africans in England: results from the Mayisha II survey of sexual attitudes and lifestyles. Sex Transm Infect, 83(7), 523-529.

UNAIDS/WHO. (2000). Guidelines for Second Generation HIV Surveillance. Geneva, Switzerland: UNAIDS/WHO.

Veen MG van, Koedijk FDH, Broek IVF van den, Op de Coul ELM, Boer IM de, Sighem AI van, et al. (2007). Sexually Transmitted Infections in the Netherlands in 2006 (No. 210261003/2007). Bilthoven: Centre for Infectious Disease Control - National Institute for Public Health and the Environment (RIVM).

Wiggers, L. C., de Wit, J. B., Gras, M. J., Coutinho, R. A., \& van den Hoek, A. (2003). Risk behavior and social-cognitive determinants of condom use among ethnic minority communities in Amsterdam. AIDS Educ Prev, 15(5), 430-447. 
Table 1 Characteristics of the study population according to sexual mixing pattern.

\begin{tabular}{|c|c|c|c|c|c|c|c|c|c|}
\hline \multirow{3}{*}{ Socio demographic characteristics } & \multirow{2}{*}{\multicolumn{2}{|c|}{$\begin{array}{c}\text { Assortative } \\
\text { No mixing } \\
\text { (group 1) } \\
\mathbf{N}=986\end{array}$}} & \multicolumn{6}{|c|}{ Disassortative } & \multirow[b]{2}{*}{ P-value $^{\text {a }}$} \\
\hline & & & \multicolumn{2}{|c|}{$\begin{array}{c}\text { Mixing with } \\
\text { Dutch (group 2) } \\
\text { N = 244 }\end{array}$} & \multicolumn{2}{|c|}{$\begin{array}{l}\text { Mixing with } \\
\text { non-Dutch } \\
\text { (group 3) } \\
\text { N = 361 }\end{array}$} & \multicolumn{2}{|c|}{$\begin{array}{c}\text { Mixing with } \\
\text { Dutch and non- } \\
\text { Dutch (group 4) } \\
\text { N = 89 }\end{array}$} & \\
\hline & \multicolumn{2}{|c|}{20} & \multirow{5}{*}{$\begin{array}{l}\text { years } \\
28 \\
18 \\
18\end{array}$} & \multirow{5}{*}{$\begin{array}{l}\text { IQR } \\
22-40 \\
12-25 \\
9-24\end{array}$} & \multirow{5}{*}{$\begin{array}{l}\text { years } \\
24 \\
16 \\
18\end{array}$} & \multirow{5}{*}{$\begin{array}{l}\mathbf{I Q R} \\
21-35 \\
8-23 \\
12-22\end{array}$} & \multirow{5}{*}{$\begin{array}{l}\text { years } \\
23 \\
13 \\
16\end{array}$} & \multirow{5}{*}{$\begin{array}{l}\text { IQR } \\
20-30 \\
6-21 \\
7-20\end{array}$} & \multirow{6}{*}{$\begin{array}{l}<0.0001 \\
<0.0001 \\
<0.0001 \\
0.07\end{array}$} \\
\hline & years & IQR & & & & & & & \\
\hline Age (median) & 30 & $22-40$ & & & & & & & \\
\hline Age at migration (median) & 20 & $13-27$ & & & & & & & \\
\hline $\begin{array}{l}\text { Years of residence in Netherlands } \\
\text { (median) }\end{array}$ & 15 & $6-21$ & & & & & & & \\
\hline HIV prevalence & \multicolumn{2}{|c|}{$0.6 \%[0.2-1.4 \%]$} & \multicolumn{2}{|c|}{$0.4 \%[0.0-2.6 \%]$} & \multicolumn{2}{|c|}{$0.6 \%[0.1-2.0 \%]$} & \multicolumn{2}{|l|}{$0.0 \%$} & \\
\hline & $\mathbf{N}$ & $\%$ & $\mathbf{N}$ & $\%$ & $\mathbf{N}$ & $\%$ & $\mathbf{N}$ & $\%$ & \\
\hline Male sex & 491 & 50 & 191 & 78 & 224 & 62 & 82 & 92 & $<0.0001$ \\
\hline Ethnicity & & & & & & & & & 0.002 \\
\hline Hindo-Surinamese & 171 & 17 & 43 & 18 & 46 & 13 & 13 & 15 & \\
\hline Afro Surinamese & 200 & 20 & 57 & 23 & 107 & 30 & 22 & 25 & \\
\hline Antillean & 331 & 34 & 77 & 32 & 115 & 32 & 28 & 31 & \\
\hline Ghanaian & 191 & 19 & 53 & 22 & 46 & 13 & 19 & 21 & \\
\hline Cape Verdeans & 93 & 9 & 14 & 6 & 47 & 13 & 7 & 9 & \\
\hline second-generation migrant & 167 & 17 & 63 & 26 & 110 & 31 & 19 & 21 & $<0.0001$ \\
\hline $\begin{array}{l}\text { Educational level } \\
\text { Low }\end{array}$ & 97 & 10 & 28 & 12 & 23 & 6 & 7 & & 0.009 \\
\hline $\begin{array}{l}\text { Low } \\
\text { Middle }\end{array}$ & 748 & 76 & 167 & 69 & 264 & 73 & 72 & $\begin{array}{l}9 \\
81\end{array}$ & \\
\hline High & 137 & 14 & 48 & 20 & 73 & 20 & 10 & 11 & \\
\hline Marital status & & & & & & & & & $<0.0001$ \\
\hline Married & 183 & 19 & 32 & 13 & 32 & 9 & 3 & 3 & \\
\hline Co-habiting & 219 & 22 & 68 & 28 & 70 & 20 & 20 & 22 & \\
\hline Single & 535 & 54 & 134 & 57 & 242 & 68 & 63 & 71 & \\
\hline Divorced & 38 & 4 & 6 & 2 & 13 & 4 & 2 & 2 & \\
\hline Widow(er) & 4 & 0.4 & 1 & 0.4 & 1 & 0.3 & 1 & 1 & \\
\hline Sexual characteristics & & & & & & & & & \\
\hline
\end{tabular}




\begin{tabular}{|c|c|c|c|c|c|c|c|c|c|}
\hline Steady partner & 818 & 83 & 160 & 66 & 242 & 67 & 50 & 56 & $<0.0001$ \\
\hline $\begin{array}{l}\text { Duration steady relationship in years } \\
\text { (median, IQR) }\end{array}$ & 4 & $2-10$ & 3 & $2-7$ & 3 & $1-5$ & 2 & $1-3$ & $<0.0001$ \\
\hline Casual partner(s) in past 6 months & 287 & 29 & 140 & 57 & 222 & 62 & 89 & 100 & $<0.0001$ \\
\hline Concurrent casual partner ${ }^{\mathrm{b}}$ & 100 & 10 & 46 & 19 & 85 & 24 & 37 & 42 & $<0.0001$ \\
\hline Condom use (cu) & & & & & & & & & $<0.0001$ \\
\hline 1. Consistent cu, all partners & 101 & 10 & 18 & 7 & 35 & 10 & 13 & 15 & \\
\hline $\begin{array}{l}\text { 2. Inconsistent cu, steady partners } \\
\text { (and/or consistent cu casual } \\
\text { partners) }\end{array}$ & 729 & 74 & 160 & 65 & 217 & 60 & 38 & 43 & \\
\hline $\begin{array}{l}\text { 3. Inconsistent cu, casual partners } \\
\text { (with/without consistent cu, steady } \\
\text { partner) }\end{array}$ & 149 & 15 & 65 & 27 & 107 & 30 & 38 & 43 & \\
\hline $\begin{array}{l}\text { Number of partners in past } 5 \text { years } \\
\text { (median, IQR) }\end{array}$ & 2 & $1-4$ & 3 & $1-8$ & 4 & $2-8$ & 8 & $5-15$ & $<0.0001$ \\
\hline $\begin{array}{l}\text { More than } 4 \text { partners in the past } 6 \\
\text { months }\end{array}$ & 26 & 3 & 22 & 9 & 38 & 11 & 42 & 47 & \\
\hline Anal sex contacts & 161 & 18 & 61 & 19 & 79 & 25 & 18 & 6 & 0.003 \\
\hline Commercial sex contact ever & 85 & 9 & 41 & 17 & 47 & 13 & 25 & 28 & $<0.0001$ \\
\hline STI check-up in past year & 166 & 17 & 36 & 15 & 85 & 25 & 19 & 22 & 0.01 \\
\hline STI diagnosis in past year ${ }^{c}$ & 35 & 21 & 6 & 17 & 18 & 21 & 6 & 32 & \\
\hline Visit to home country in past 5 years & 616 & 63 & 124 & 51 & 201 & 56 & 41 & 46 & 0.0002 \\
\hline Ever injected drugs & 19 & 2 & 9 & 4 & 6 & 2 & 4 & 5 & 0.18 \\
\hline
\end{tabular}

a univariate multinomial regression analysis

${ }^{\mathrm{b}}$ concurrent casual partner in participants involved in a steady relationship of more than 6 months

${ }^{c}$ percentage of those tested for STI in past year 
Table 2 Associations with disassortative mixing $(\mathrm{n}=1680)$ using multivariate multinomial regression analyses.

\begin{tabular}{|c|c|c|c|c|c|c|c|}
\hline & \multicolumn{2}{|c|}{$\begin{array}{l}\text { Mixing with Dutch } \\
\text { (group 2) } N=244\end{array}$} & \multicolumn{2}{|c|}{$\begin{array}{c}\text { Mixing with non- } \\
\text { Dutch (group 3) } \\
\text { N = 361 }\end{array}$} & \multicolumn{2}{|c|}{$\begin{array}{l}\text { Mixing with both } \\
\text { (group 4) N = 89 }\end{array}$} & \multirow[t]{2}{*}{$\begin{array}{l}\text { Overall p- } \\
\text { value }\end{array}$} \\
\hline & OR & $95 \% \mathrm{CI}$ & OR & $95 \% \mathrm{CI}$ & OR & $95 \% \mathrm{CI}$ & \\
\hline Sex \& condom use (cu) & & & & & & & $<0.0001$ \\
\hline $\begin{array}{l}\text { Women \& Inconsistent cu, steady partners } \\
\text { (consistent cu, casual partners) }\end{array}$ & 0.55 & $0.37-0.82$ & 0.84 & $0.62-1.14$ & 0.11 & $0.02-0.58$ & \\
\hline $\begin{array}{l}\text { Women \& Inconsistent cu, casual partners } \\
\text { (with/without consistent cu, steady partner) }\end{array}$ & 0.60 & $0.31-1.15$ & 1.52 & 1.01-2.29 & 1.29 & $0.50-3.33$ & \\
\hline Men \& Consistent cu, all partners & 0.76 & $0.41-1.41$ & 0.65 & $0.39-1.08$ & 1.66 & $0.75-3.65$ & \\
\hline $\begin{array}{l}\text { Men \& Inconsistent cu, steady partners (consistent } \\
\text { cu, casual partners) }\end{array}$ & 1.76 & $1.30-2.38$ & 1.02 & $0.78-1.33$ & 1.22 & $0.66-2.28$ & \\
\hline $\begin{array}{l}\text { Men \& Inconsistent cu, casual partners (with/without } \\
\text { consistent cu, steady partner) }\end{array}$ & 2.33 & 1.54-3.51 & 1.20 & $0.83-1.73$ & 2.33 & $1.54-3.51$ & \\
\hline Concurrent casual partner & 1.26 & $1.00-1.56$ & 1.49 & 1.23-1.81 & 1.56 & $1.17-2.06$ & 0.0002 \\
\hline Ethnicity & & & & & & & 0.02 \\
\hline Hindo-Surinamese & 1.04 & $0.74-1.45$ & 0.64 & $0.46-0.88$ & 0.95 & $0.54-1.66$ & \\
\hline Afro-Surinamese & 1.43 & 1.05-1.95 & 1.41 & 1.09-1.82 & 1.27 & $0.79-2.06$ & \\
\hline Antillean & 1.10 & $0.83-1.47$ & 1.08 & $0.85-1.37$ & 0.86 & $0.55-1.36$ & \\
\hline Ghanaian & 1.16 & $0.84-1.61$ & 0.82 & $0.60-1.13$ & 1.26 & $0.76-2.11$ & \\
\hline Second-generation migrant & 1.26 & 1.04-1.54 & 1.34 & 1.13-1.58 & 0.94 & $0.67-1.30$ & 0.001 \\
\hline Educational level & & & & & & & 0.02 \\
\hline Middle & 0.76 & $0.61-0.96$ & 0.96 & $0.77-1.20$ & 1.10 & $0.73-1.65$ & \\
\hline High & 1.22 & $0.91-1.64$ & 1.52 & 1.16-2.01 & 0.93 & $0.54-1.61$ & \\
\hline Number of partners in last 5 years & & & & & & & $<0.0001$ \\
\hline 3 partners & 0.78 & $0.54-1.13$ & 0.98 & $0.74-1.31$ & 0.76 & $0.38-1.52$ & \\
\hline 4-6 partners & 1.12 & $0.82-1.53$ & 1.28 & $0.99-1.66$ & 1.95 & $1.20-3.15$ & \\
\hline$>=7$ partners & 1.32 & $0.98-1.78$ & 1.48 & 1.13-1.92 & 3.51 & 2.24-5.50 & \\
\hline Visit to home country in past 5 years & $\mathbf{0 . 8 2}$ & $0.70-0.96$ & $\mathbf{0 . 8 2}$ & $0.72-0.94$ & 0.68 & $\mathbf{0 . 5 3 - 0 . 8 7}$ & 0.001 \\
\hline
\end{tabular}


Table 3 Associations with disassortative mixing in participants with 2 or more partners $(\mathrm{n}=557)$, using multivariate multinomial regression analyses.

\begin{tabular}{|c|c|c|c|c|c|c|c|}
\hline & \multicolumn{2}{|c|}{$\begin{array}{c}\text { Mixing with Dutch } \\
\text { (group 2) } \\
\text { N }=105\end{array}$} & \multicolumn{2}{|c|}{$\begin{array}{l}\text { Mixing with non- } \\
\text { Dutch (group 3) } \\
\text { N = 175 }\end{array}$} & \multicolumn{2}{|c|}{$\begin{array}{c}\text { Mixing with both } \\
\text { (group 4) } \\
\text { N = 87 }\end{array}$} & \multirow[t]{2}{*}{$\begin{array}{l}\text { Overall p- } \\
\text { value }\end{array}$} \\
\hline & OR & $95 \% \mathrm{CI}$ & OR & $95 \% \mathrm{CI}$ & OR & $95 \% \mathrm{CI}$ & \\
\hline Sex \& condom use & & & & & & & NA \\
\hline $\begin{array}{l}\text { Women \& Inconsistent cu, steady partners } \\
\text { (consistent cu, casual partners) }\end{array}$ & 2.58 & $0.92-7.21$ & 1.07 & $0.63-1.79$ & 0.53 & $0.21-1.36$ & \\
\hline $\begin{array}{l}\text { Women \& Inconsistent cu, casual partners } \\
\text { (with/without consistent cu, steady partner) }\end{array}$ & 3.25 & $0.68-15.55$ & 1.27 & $0.60-2.71$ & 0.36 & $0.06-2.07$ & \\
\hline Men \& Consistent cu, all partners & 4.03 & 1.26-12.92 & 1.01 & $0.52-1.94$ & 2.55 & 1.13-5.75 & \\
\hline $\begin{array}{l}\text { Men \& Inconsistent cu, steady partners (consistent } \\
\text { cu, casual partners) }\end{array}$ & 14.33 & NA & 1.52 & $0.98-2.36$ & 2.48 & $1.30-4.72$ & \\
\hline $\begin{array}{l}\text { Men \& Inconsistent cu, casual partners (with/without } \\
\text { consistent cu, steady partner) }\end{array}$ & 11.70 & 6.79-20.17 & 0.88 & $0.58-1.36$ & 1.52 & $0.80-2.88$ & \\
\hline Visit to home country in past 5 years & 0.80 & $0.62-1.02$ & 0.81 & $0.65-1.00$ & 0.68 & $0.52-0.88$ & 0.03 \\
\hline
\end{tabular}

$\mathrm{NA}=$ Not accountable (infinite) 